Pengembangan Rekayasa dan Teknologi, Vol 15, No. 1, Juni 2019, pp 21-26

p-ISSN: 1410-9840 \& e-ISSN: 2580-8850

http://journals.usm.ac.id/index.php/jprt/index

\title{
PERANCANGAN SISTEM PEMILIHAN BUDIDAYA IKAN AIR TAWAR BERBASIS WEB
}

\author{
${ }^{1}$ Prind Triajeng Pungkasanti, ${ }^{2}$ Saifur Rohman Cholil, ${ }^{3}$ B. Very Christioko \\ ${ }^{1,2}$ Program Studi Sistem Informasi Universitas Semarang \\ ${ }^{3}$ Program Studi Teknik InformatikaUniversitas Semarang \\ ${ }^{1}$ prind@usm.ac.id, ${ }^{2}$ cholil@usm.ac.id, ${ }^{3}$ very@usm.ac.id
}

\begin{abstract}
Abstrak
Pertumbuhan perekonomian Indonesia dan potensi budidaya ikan air tawar semakin meningkat, hal ini terjadi karena kesadaran masyarakat akan pentingnya mengkonsumsi ikan yang terus meningkat serta adanya program Gemar Makan Ikan yang dipopulerkan oleh KKP (Kementerian Kelautan dan Perikanan). Potensi Budidaya air tawar memiliki prospek yang baik kedepannya diantaranya ikan Lele, ikan Gurame, ikan Nila, ikan Mujair dan ikan Patin. Alternatif ikan ini memiliki karakteristik yang berbeda untuk masing-masing jenis pembudidayaannya. Kriteria dipengaruhi pada faktor kesesuaian air yang meliputi: suhu, kecerahan, DO (Disolved Oxygen), keasaman ( $\mathrm{pH})$. Namun belum ada alat bantu yang dapat memudahkan petani ikan air tawar dalam melakukan pemilihan ikan air tawar. Maka dibutuhkan sistem pemilihan ikan air tawar untuk memberikan informasi kepada para petani ikan air tawar. Perancangan sistem pemilihan air tawar ini menggunakan tahap pelaksanaan komunikasi, analisis, dan desain. Perancangan desain dilakukan dengan UML (Unified Modeling Language) yang terdiri dari : use case diagram, sequence diagram, activity diagram, class diagram; perancangan interface menggunakan bahasa pemrograman PHP dan perancangan database menggunakan MySQL.
\end{abstract}

Kata kunci : Budidaya, Ikan air tawar, Web

\begin{abstract}
Indonesia's economic growth and the potential for freshwater fish cultivation are increasing, this is due to public awareness of the importance of consuming fish that continues to increase as well as the existence of a Fish Eating program popularized by KKP (Ministry of Marine Affairs and Fisheries). The potential of freshwater cultivation has good prospects going forward including catfish, Gurame fish, tilapia, Mujair fish and Patin fish. This alternative fish has different characteristics for each type of cultivation. Criteria are influenced by water suitability factors which include: temperature, brightness, DO (Dissolved Oxygen), acidity ( $p H$ ). However, there are no tools that can facilitate freshwater fish farmers in selecting freshwater fish. Then we need a freshwater fish selection system to provide information to freshwater fish farmers. The design of this freshwater selection system uses the stages of communication, analysis, and design. Design is done with UML (Unified Modeling Language) which consists of: use case diagrams, sequence diagrams, activity diagrams, class diagrams; interface design uses the PHP programming language and database design using MySQL.
\end{abstract}

Keywords: Cultivation, Freshwater fish, Web

\section{PENDAHULUAN}

Indonesia memiliki potensi yang sangat besar dibidang maritim atau kelautan karena luas wilayahnya melebihi wilayah daratan.. Hal ini menyebabkan potensi usaha perikanan Indonesia semakin menggiurkan, baik produksi ikan laut maupun produksi ikan air tawar. Meningkatnya permintaan ikan disebabkan oleh adanya kesadaran masyarakat akan pentingnya menkonsumsi ikan yang semakin tinggi serta adanya program Gemar Makan Ikan (GMI) yang dipopulerkan oleh Kementrian Kelautan dan Perikanan sehingga menyebabkan angka konsumsi akan terus naik, terutama permintaan akan ikan air tawar.

Produksi perikanan air tawar yang ada selama ini didominasi oleh ikan Lele, Gurame, Nilai, Mujair dan Patin. Jenis-jenis ikan yang telah disebutkan menyumbang di atas $80 \%$ dari keseluruhan total produksi yang ada selama ini. Sisanya adalah budidaya ikan air laut, budidaya tambak air payau, jaring apung dan karamba. Karakteristik dari masing-masing alternatif ikan ini memiliki penanganan yang berbeda untuk masing-masing jenis pembudidayaannya. Pertimbangan untuk pemilihan budidaya ikan air tawar dipengaruhi oleh faktor suhu, kecerahan, DO (Dissolved Oxygen), keasaman $(\mathrm{pH})$. Supaya memudahkan para petani ikan air tawar dalam menentukan ikan mana yang layak untuk dibudidayakan, maka dibutuhkan sebuah sistem yang dapat memberikan informasi yang nantinya dapat digunakan para petani ikan sebagai dasar dalam melakukan budidaya ikan.

Perancangan sistem pemilihan budidaya ikan tawar ini menggunakan Unified Modeling Language (UML). UML digunakan dalam penelitian ini untuk mempermudah analisa sistem yang akan dibuat.

\section{TINJAUAN PUSTAKA}

1. Sistem Informasi

1.1 Sistem

Secara arti sistem adalah sebuah himpunan atau sekumpulan dari satu unsur, variabel atau komponen 
Pengembangan Rekayasa dan Teknologi, Vol 15, No. 1, Juni 2019, pp 21-26

p-ISSN: 1410-9840 \& e-ISSN: 2580-8850

http://journals.usm.ac.id/index.php/jprt/index

yang terorganisir, bergantung antara satu dengan yang lain (Sutabri, 2012). Pendapat lain yang menjelaskan tentang definisi sistem adalah kumpulan beberapa elemen yang saling berkaitan untuk mencapai tujuan yang diinginkan (Kadir, 2014).

\subsection{Informasi}

Informasi didefinisikan sebagai data yang sudah diolah atau diklasifikasikan yang digunakan untuk proses pengambilan keputusan. Pengolahan dari sistem informasi yaitu mengolah data yang ada atau data biasa menjadi data yang dapat digunakan oleh penerimanya atau mempunyai nilai manfaat. (Sutabri, 2012).

\subsection{Sistem Informasi}

Gabungan dari definisi Sistem dan Informasi adalah pengolahan elemen yang menjadi satu kesatuan informasi yang baik untuk diorganisasikan sehingga mencapai tujuan dalam organisasi atau kelompok (Kadir, 2014).

\subsection{Budidaya Ikan Tawar}

Peningkatan produksi ika nasional terus-menerus mengalami kenaikan. Data yang diperoleh menunjukan tahun 2011 sebesar 12,39 juta ton dan produksi tangkap ikan sebanyak 5,41 juta ton, sedangkan produksi budidaya perikanan mencapai 6,98 juta ton. Jumlah prosuksi budidaya perikanan air tawar menyumbangkan angka hingga 1,1 juta ton. Sisanya adalah budidaya tambak air payau, budidaya di laut, budidaya dalam keramba dan budidaya jaring apung.

Kenaikan cukup tinggi dari budidaya ikan air tawar sebesar 11 persen setiap tahun. Dominasi budidaya ikan air tawar yang ada selama ini adalah ikan mas, ikan lele, ikan patin, ikan nila dan ikan gurame. Jenis ikan yang disebutkan tersebut menyumbang di atas 80 persen dari total produksi yang ada (Kementerian Kelautan dan Perikanan, 2015).

Kesesuain hidup ikan dengan lingkungannya banyak dipengaruhi oleh beberapa faktor lingkungannya. Diantaranya adalah kondisi air untuk budidaya yang bisa diukur melalui beberapa parameter seperti dilihat pada Tabel 1.

Tabel 1. Perbandingan nilai kualitas air untuk budidaya ikan tawar

\begin{tabular}{|l|l|c|}
\hline No & \multicolumn{1}{|c|}{ Paramater } & Kondisi Perairan Ideal \\
\hline 1 & Suhu & $23^{0} \mathrm{C}-28^{0} \mathrm{C}$ \\
\hline 2 & Kecerahan air & 2 Meter \\
\hline 3 & Oksigen terlarut & $>5 \mathrm{mg} / \mathrm{L}$ \\
\hline 4 & pH air & $6,8-8,5$ \\
\hline
\end{tabular}

\section{UML (Unified Modeling Language)}

Permodelan arsitektur yang menggambarkan pemrograman diantaranya menggunakan UML. UML banyak digunakan di dunia information technology untuk membuat analisis, mendefinisikan kebutuhan (requirement) dan membuat desain perangkat lunak. Permodelan sistem dengan menggunakan UML merupakan bahasa visual untuk menjelaskan tentang sistem yang akan dibuat dengan diagram dan file pendukung lainnya. Analisis kebutuhan permodelan UML digunakan untuk membuat spesifikasi, penggambaran sistem, membangun sistem, dan dokumentasi dari perangkat lunak sistem yang dibuat (Rosa, 2013).

\section{1) Use Case Diagram}

Permodelan untuk menunjukkan tingkah laku atau kelakukan dari sistem informasi yang akan dibuat menggunakan Use Case Diagram. Permodelan ini mendeskripsikan sebuah hubungan antara satu entitas atau lebih aktor dengan sistem yang akan dibuat (Rosa, 2013).

2) Class Diagram

Diagram kelas atau class diagram digunakan untuk menggambarkan struktur sistem dengan cara menndefinisikan kelas yang akan dibuat atau dirancang untuk membangun sebuah sistem. Pembuatan sebuah kelas diharuskan memiliki atribut dan metode atau operasi (Rosa, 2013).

\section{3) Sequence Diagram}

Sequence diagram adalah diagram yang menggambarkan perilaku objek pada use case diagram dengan cara mendeskripsikan waktu objek dan pesan yang dikirimkan dan diterima antar masing-masing objek. Penggambaran sequence diagram harus diketahui oleh objek-objek yang terlibat didalam sebuah use case diagram beserta keseluruhan metode yang dimiliki kelas yang diinstansisasi menjadi objek (Rosa, 2013).

\section{4) Activity Diagram}

Activity diagram adalah aktivitas dari sebuah sistem yang menggambarkan secara rinci aliran kerja atau menu yang ada pada sistem. Activity diagram mejelasakan urutan aktivitas pada proses bisnis. Dasar pembuatan activity diagram berdasarkan use case diagram yang sudah dibuat.(Rosa, 2013).

\section{METODE PENELITIAN}

Pengumpulan data yang dilakukan oleh peneliti dengan cara melakukan wawancara dan studi literatur. Peneliti melakukan wawancara dan pengambilan data kepada staf Dinas Kelautan dan Perikanan Propinsi Jawa Tengah. Pengumpulan data yang dilakukan melalui literatur adalah mencari informasi jurnal dan buku tentang pemilihan budidaya ikan tawar.

\section{Metode Pelaksanaan}

Metode pelaksanaan yang dilakukan menggunakan pada penelitian ini terdiri dari beberapa langkah, yaitu: 
Pengembangan Rekayasa dan Teknologi, Vol 15, No. 1, Juni 2019, pp 21-26

p-ISSN: $1410-9840$ \& e-ISSN: 2580-8850

http://journals.usm.ac.id/index.php/jprt/index

a. Komunikasi: pada tahap ini peneliti melakukan komunikasi untuk mendapatkan gambaran tentang permasalahan pemilihan budidaya ikan tawar yang dihadapi.

b. Analisis: pada tahap ini peneliti menganalisa kebutuhan perangkat lunak yang nantikan akan menjadi perancangan interface dan database.

c. Desain: merancang alur sistem dan tampilan system pemilihan budidaya ikan tawar.

\section{HASIL DAN PEMBAHASAN}

\section{Kebutuhan Perangkat Lunak}

Kebutuhan perangkat lunak yang digunakan untuk mengimplementasikan sistem pemilihan ikan air tawar terdiri dari :

a. MySQL untuk database

b. Bahasa pemrograman menggunakan PHP

\section{Perancangan Alur Sistem}

a. Use Case Diagram

Perancangan use case diagram ditunjukkan oleh Gambar 1.

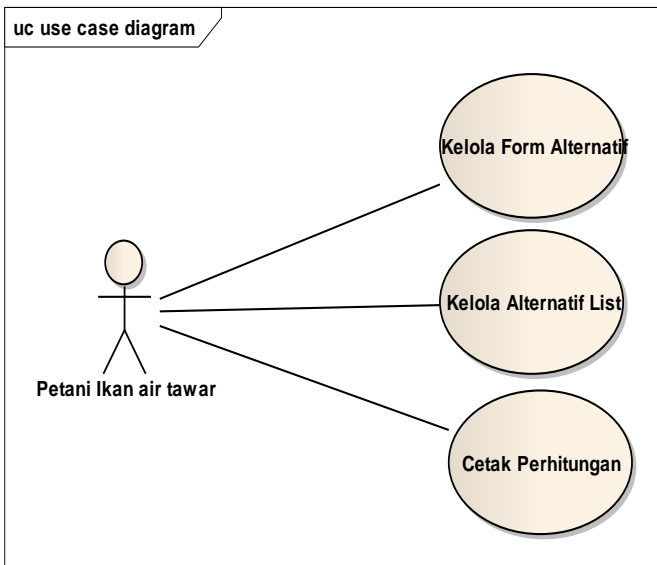

Gambar 1. Use Case Diagram Pemilihan Ikan Air Tawar

b. Sequence Diagram Kelola Form Alternatif Perancangan sequence diagram kelola form alternatif ditunjukkan oleh Gambar 2.

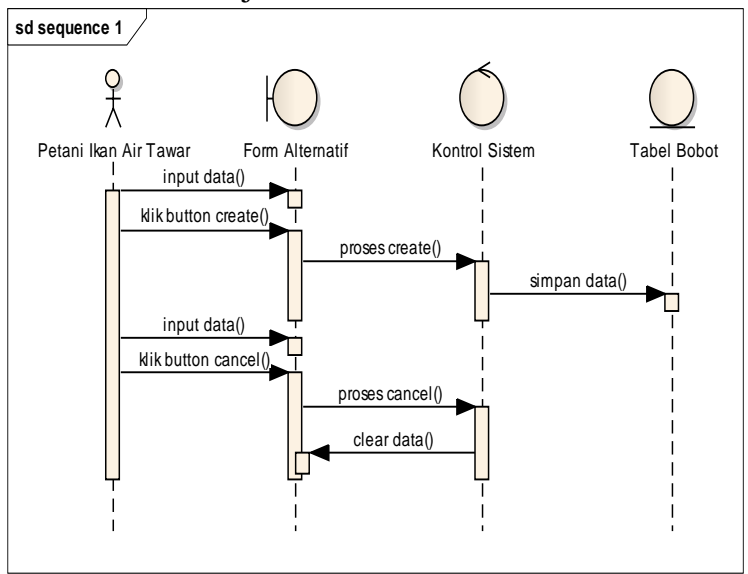

Gambar 2. Sequence Diagram Kelola Form Alernatif

c. Sequence Diagram Kelola Alternatif List

Perancangan sequence diagram kelola alternatif list ditunjukkan oleh Gambar 3.

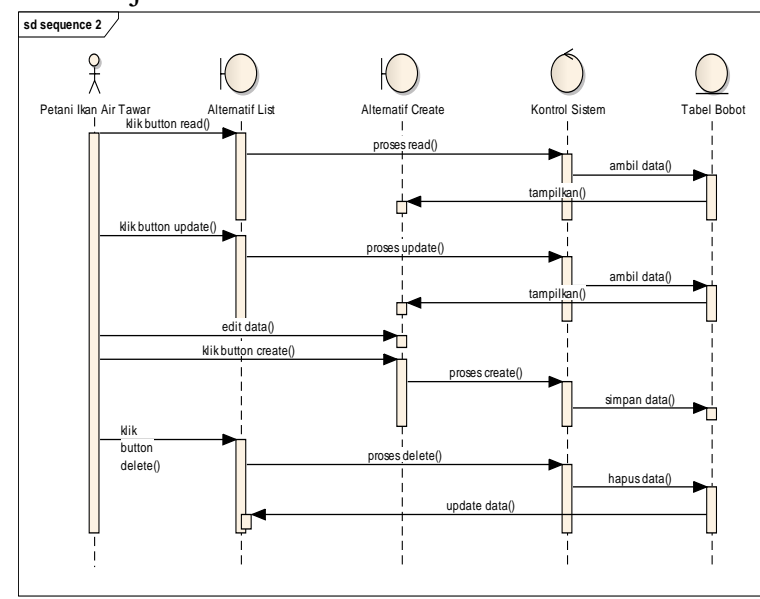

Gambar 3. Sequence Diagram Kelola Alternatf List

d. Sequence Diagram Hasil Perhitungan

Perancangan sequence diagram hasil perhitungan ditunjukkan oleh Gambar 4.

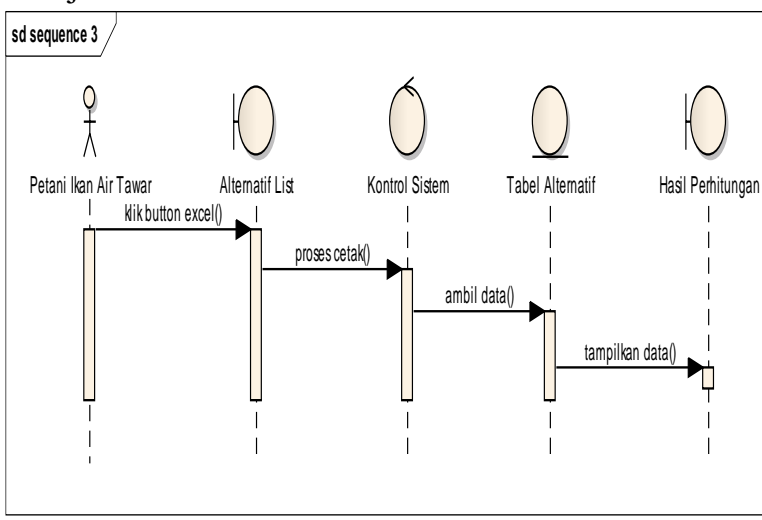

Gambar 4. Sequence Diagram Hasil Perhitungan

e. Activity Diagram Kelola Form Alternatif

Perancangan activity diagram kelola form alternatif ditunjukkan oleh Gambar 5. 
Pengembangan Rekayasa dan Teknologi, Vol 15, No. 1, Juni 2019, pp 21-26

p-ISSN: 1410-9840 \& e-ISSN: 2580-8850

http://journals.usm.ac.id/index.php/jprt/index
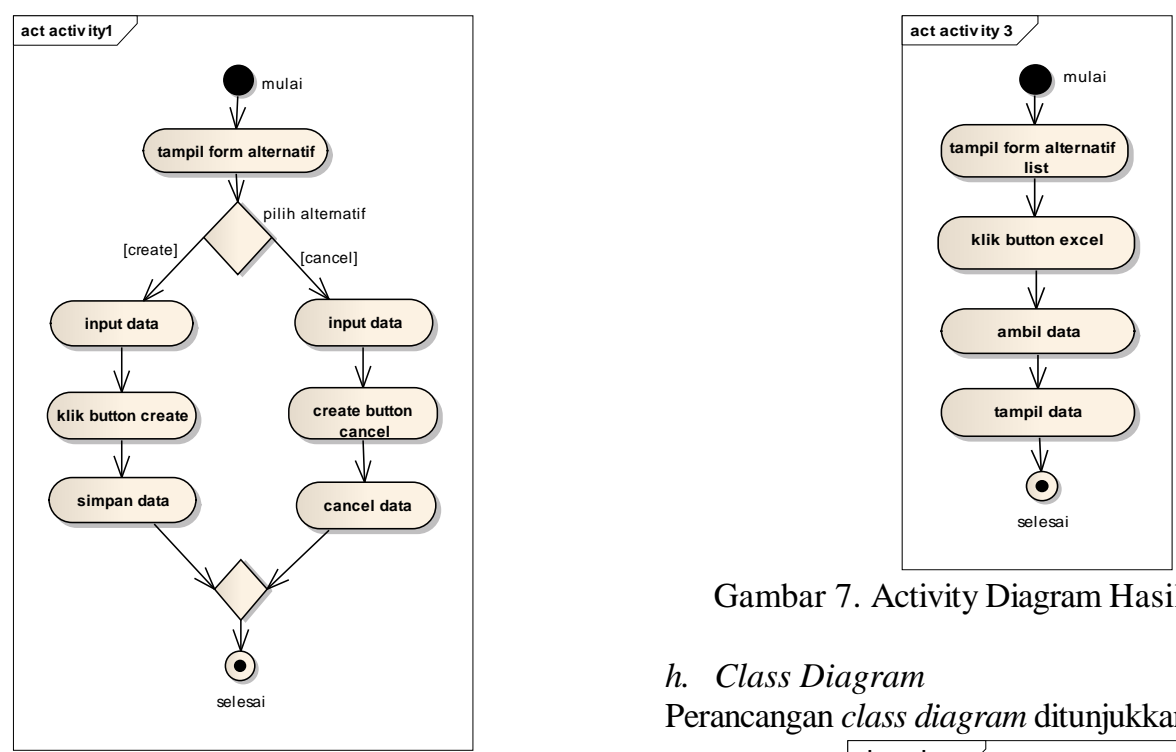

Gambar 7. Activity Diagram Hasil Perhitungan

\section{h. Class Diagram}

Perancangan class diagram ditunjukkan oleh Gambar 8.

Gambar 5. Activity Diagram Kelola Form Alternatif

f. Activity Diagram Kelola Alternatif List

Perancangan actifity diagram kelola alternatif list ditunjukkan oleh Gambar 6.

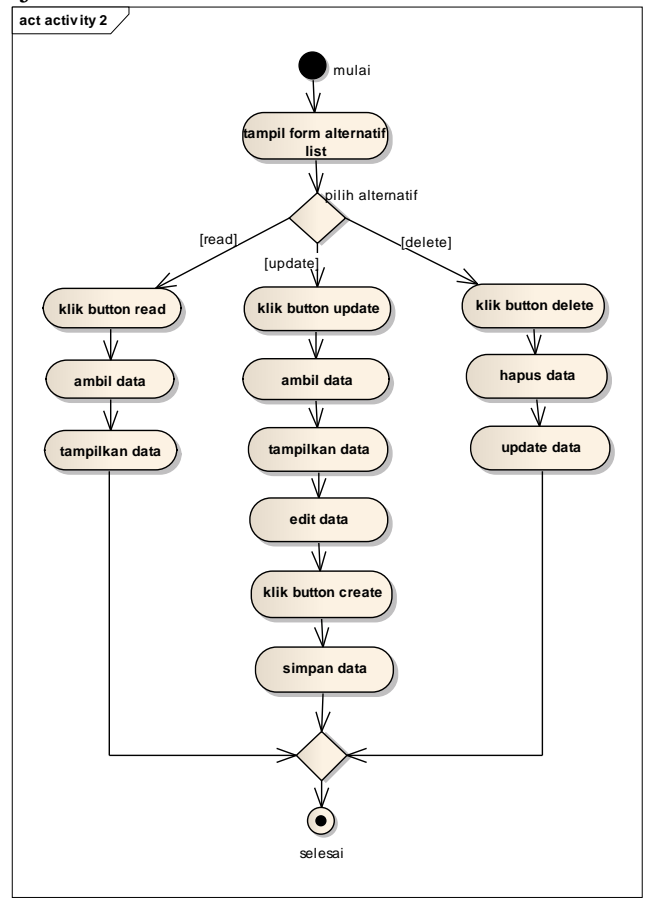

Gambar 6. Activity Diagram Kelola Alternatif List

g. Activity Diagram Hasil Perhitungan

Perancangan actifity diagram hasil perhitungan ditunjukkan oleh Gambar 7.



i. Perancangan Database

Perancangan database sistem ditunjukkan oleh Gambar 9.

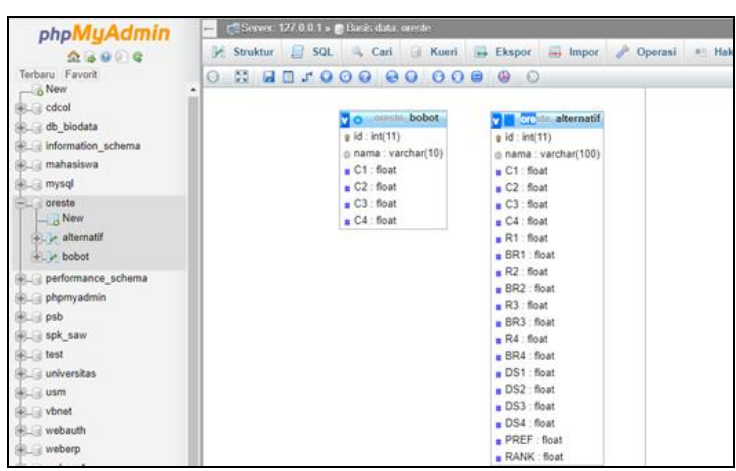

Gambar 9. Perancangan Database

j. Perancangan Tabel Bobot

Perancangan tabel bobot alternatif list ditunjukkan oleh Gambar 10 
Pengembangan Rekayasa dan Teknologi, Vol 15, No. 1, Juni 2019, pp 21-26

p-ISSN: 1410-9840 \& e-ISSN: 2580-8850

http://journals.usm.ac.id/index.php/jprt/index

\begin{tabular}{|c|c|c|c|c|c|c|c|}
\hline & \# Nama & Jenis & Penyortiran & Atribut & Kosong & Bawaan & Ekstra \\
\hline$\square$ & 1 id & $\operatorname{int}(11)$ & & & Tidak & Tidak ada & AUTO_INCREMENT \\
\hline$\square$ & 2 nama & $\operatorname{varchar}(10)$ & utfimb4_general_ci & & Tidak & Tidak ada & \\
\hline$\square$ & $3 \mathrm{C} 1$ & float & & & Tidak & Tidak ada & \\
\hline$\square$ & $4 \mathrm{C} 2$ & float & & & Tidak & Tidak ada & \\
\hline$\square$ & $5 \mathrm{C} 3$ & float & & & Tidak & Tidak ada & \\
\hline$\square$ & $6 \mathrm{C} 4$ & float & & & Tidak & Tidak ada & \\
\hline 七 & - $\square$ Pill & Semua & Dengan pilihan: & Jelajahi & 2 Ubah & h O Hapu & pus Kunci Utama \\
\hline
\end{tabular}

Gambar 10. Perancangan Tabel Bobot

k. Perancangan Tabel Alternatif

Perancangan tabel alternatif ditunjukkan oleh Gambar 11.

\begin{tabular}{|c|c|c|c|c|c|c|c|c|}
\hline & $\#$ & Nama & Jenis & Penyortiran & Atribut & Kosong & Bawaan & Ekstra \\
\hline b & 1 & id & $\operatorname{int}(11)$ & & & Tidak & Tidak ada & AUTO_INCREMENT \\
\hline b & 2 & nama & varchar $(100)$ & utf8mb4_general_ci & & Tidak & Tidak ada & \\
\hline b & 3 & C1 & float & & & Tidak & Tidak ada & \\
\hline b & 4 & $\mathrm{C} 2$ & float & & & Tidak & Tidak ada & \\
\hline b & 5 & $\mathrm{C} 3$ & float & & & Tidak & Tidak ada & \\
\hline 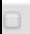 & 6 & $\mathrm{C} 4$ & float & & & Tidak & Tidak ada & \\
\hline b & 7 & R1 & float & & & Ya & NULL & \\
\hline b & 8 & BR1 & float & & & $\mathrm{Ya}$ & NULL & \\
\hline$b$ & 9 & R2 & float & & & $\mathrm{Ya}$ & NULL & \\
\hline 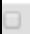 & 10 & BR2 & float & & & Ya & NULL & \\
\hline$b$ & 11 & R3 & float & & & $\mathrm{Ya}$ & NULL & \\
\hline b & 12 & BR3 & float & & & Ya & NULL & \\
\hline$b$ & 13 & R4 & float & & & $\mathrm{Ya}$ & NULL & \\
\hline b & 14 & BR4 & float & & & Ya & NULL & \\
\hline b & 15 & DS1 & float & & & $\mathrm{Ya}$ & NULL & \\
\hline b & 16 & DS2 & float & & & Ya & NULL & \\
\hline b & 17 & DS3 & float & & & Ya & NULL & \\
\hline$\theta$ & 18 & DS4 & float & & & Ya & NULL & \\
\hline$b$ & 19 & PREF & float & & & $\mathrm{Ya}$ & NULL & \\
\hline$b$ & 20 & RANK & float & & & $\mathrm{Ya}$ & NULL & \\
\hline
\end{tabular}

Gambar 11. Perancangan Tabel Alternatif

\section{Perancangan Interface}

a. Perancangan Form Alternatif

Perancangan form alternatif ini berisi nama aternatif dan data nilai pada masing-masing kriteia yang menjadi acuan dalam pemilihan budidaya ikan air tawar ditunjukkan oleh Gambar 12.

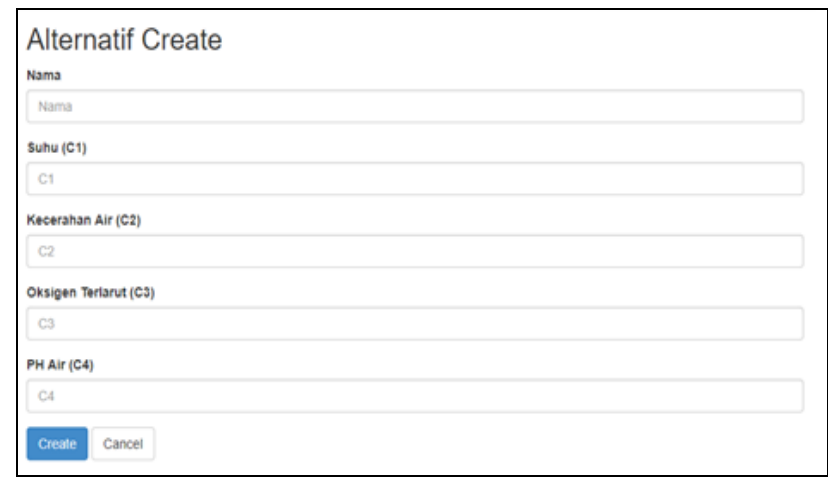

Gambar 12. Perancangan Form Alternatif

b. Perancangan Alternatif List

Perancangan alternatif list berisi informasi nama-nama alternatif yang digunakan dalam pemilihan budidaya ikan air tawar ditunjukkan oleh Gambar 13.

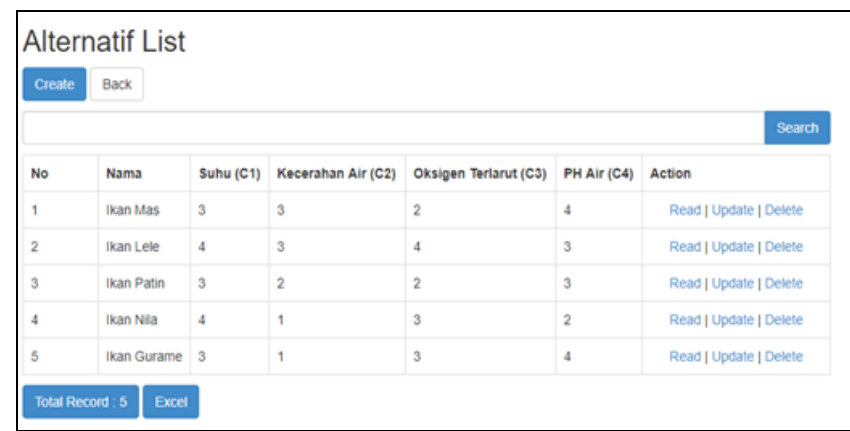

Gambar 13. Perancangan Alternatif List

c. Perancangan Hasil Perhitungan

Perancangan hasil perhitungan berisi informasi nilai dari masing-masing alternatif yang dipilih ditunjukkan oleh Gambar 14.

\begin{tabular}{|c|c|c|c|c|c|}
\hline \multicolumn{6}{|c|}{ Hasil Perhitungan } \\
\hline No & Nama Alternatif & c1 & $\mathrm{C} 2_{2}$ & c3 & C4 \\
\hline 1 & Ikan Gurame & 1.04004 & 1.12449 & 2.05942 & 2.68656 \\
\hline 2 & Ikan Nila & 2.2582 & 1.12449 & 2.05942 & 2.01036 \\
\hline 3 & Ikan Patin & 1.04004 & 1.63553 & 1.56006 & 2.15106 \\
\hline 4 & Ikan Lele & 2.2582 & 2.31401 & 2.6684 & 2.15106 \\
\hline 5 & Ikan Mas & 1.04004 & 2.31401 & 1.56006 & 2.68656 \\
\hline
\end{tabular}

Gambar 14. Perancangan Hasil Perhitungan

\section{KESIMPULAN}

Kesimpulan dari penelitian ini adalah telah terbentuknya sebuah sistem pendukung keputusan dengan metode Oreste untuk penentuan budidaya ikan tawar sehingga dapat diketahui ikan tawar jenis apa yang cocok untuk peternakan ikan yang akan dibudidayakan.

1. Hasil dari sistem ini telah diuji dan diverifikasi, dengan hasil menunjukan output yang sama di hasilkan sesuai.

2. Sistem ini dapat menentukan jenis ikan tawar yang cocok untuk peternakan yang akan dibudidayakan

\section{DAFTAR PUSTAKA}

Kadir, Abdul. (2014). Pengenalan Sistem Informasi Edisi Revisi. Andi Offset. Yogyakarta.

Kementerian Kelautan dan Perikanan. (2015). Potensi Usaha Budidaya Ikan Air Tawar. Retrieved August 28, 2018, from http://news.kkp.go.id/index.php/ potensi-usahabudidaya-ikan-air-tawar/

Kresna, A. (2017). Mengenal Kandungan Gizi Pada Ikan. Retrieved August 28, 2018, from http://dkp.jatengprov.go.id/index.php/artikel/bid 
Pengembangan Rekayasa dan Teknologi, Vol 15, No. 1, Juni 2019, pp 21-26

p-ISSN: 1410-9840 \& e-ISSN: 2580-8850

http://journals.usm.ac.id/index.php/jprt/index

angpukp/ mengenal-kandungan-gizi-pada-ikan

Raharjo, B., Heryanto, I., \& Rosdiana. (2014). Modul

Pemrograman WEB HTML, PHP dan MySQL.

Bandung: Modula.

Rosa, A. S. Dan M. Shalahuddin. (2013). Rekayasa Perangkat Lunak. Informatika. Bandung.

Sutabri, Tata. (2012). Analisis Sistem Informasi. Andi. Yogyakarta.

Triyuliana, A. (2005). Aplikasi Manajemen Database Pendidikan Berbasis Web dengan PHP dan MySQL. Yogyakarta: Andi.

Turban, E., E. Aronson, J., \& Liang, T.-P. (2007). Decision Support Systems and Business Intelligence. Decision Support and Business Intelligence Systems, 7/E, 1-35. 